\title{
Penggunaan Platform Game Education dalam Pendidikan Keperawatan: Kajian Literatur
}

\author{
Boby Nurmagandi \\ Fakultas Ilmu Keperawatan Universitas Indonesia, Depok, 16424, Indonesia \\ E-mail: nurmagandi.bob@gmail.com
}

\begin{abstract}
ABSTRAK
Perkembangan teknologi informasi dan komunikasi yang semakin pesat berdampak pada sistem Pendidikan dimana proses pembelajaran berkembang menjadi berbasis elektronik, Penggunaan sistem pembelajaran berbasis elektronik dalam Pendidikan keperawatan mampu menciptakan pengalaman yang menarik bagi mahasiswa. salah satunya penggunaan paltform game education. Penggunaan Platform game education dapat memberikan kemudahan dalam memahami sistem pembelajaran. Metode penulisan artikel ini adalah studi Literature Review melalui pencarian artikel pada 2 data based, yaitu: Science Direct dan Scopus. Kriteria inklusi studi literatur ini adalah free fulltext, berbahasa inggris, dan terbit tahun 2013-2018. kata kunci yang digunakan dalam pencarian artikel adalah Game, Education Game, Platform game education, Game Education Nursing. hasil pencarian ditemukan 294 artikel kemudian direview dengan membaca bagian judul dan abstrak hingga ditemukan 10 artikel yang relevan untuk dijadikan bahan kajian literatur. Hasil kajian lietaratur menyimpulkan bahwa Penggunaan platform game education dalam proses pembelajaran dapat meningkatkan minat belajar, tingkat kepuasan mahasiswa, meningkatkan selfefficacy, tingkat penalaran serta kemampuan dalam pengambilan keputusan. penggunaan game education juga mampu meningkatan prose belajar mahasiswa, tercipta susasan pembelajaran yang aktif, materi pembelajaran mudah dipahami, serta meningkatkan kemampuan praktik klinis mahasiwa. Perlunya pengembangan studi lebih lanjut terkait penggunaan platform game education, kerjasama antara institusi Pendidikan dengan pihak terkait khususnya industri game untuk pengembangan platform game education sesuai dengan kebutuhan dalam proses pembelajaran.
\end{abstract}

Kata Kunci: Game, Game Edukasi, Pendidikan Keperawatan

\begin{abstract}
Development of information and communication technology that increases complexity in the education system where the learning process develops to be electronic-based, the use of electronic-based learning systems in nursing education provides an interesting development for students. one of them is the use of educational game platforms. The use of educational game platforms can provide convenience in learning the learning system. The method of reading this article is the Study of Literature Review through searching articles on 2 data-based, namely: Science Direct and Scopus. The inclusion criteria for this literature study are full text free, waiting for English, and published 2013-2018. The keywords used in the search article are Games, Educational Games, Platform Educational Games, Nursing Educational Games. search results found 294 articles starting with reading the title and abstract sections to find 10 articles that are relevant for use for literature review. The results of the conclusions study concluded that the use of educational game platforms in the learning process can increase learning interest, student satisfaction levels, increase self-efficacy, the level of punishment and the ability to make decisions. The use of educational games can also increase student learning prose, create active learning arrangements, easy to understand learning material, and improve students' clinical teaching skills. Educational games related to educational game platforms, collaboration between education and related parties Industrial games to educate game platforms according to the needs in the learning process.
\end{abstract}

Keywords: Games, Educational Games, Nursing Education

Korespondensi Author: Boby Nurmagandi, Mahasiswa Magister Fakultas Ilmu Keperawatan Universitas Indonesia, E-mail : nurmagandi.bob@gmail.com,Telp.085398844808 


\section{LATAR BELAKANG}

Perkembangan yang pesat di era globalisasi saat ini khususnya dibidang teknologi, membuat manusia memasuki era revolusi industry 4.0 yang berfokus pada artificial intelligence, big data, robotic dan digital economy. Dunia Pendidikan khususnya Pendidikan keperawatan ikut terdampak pada era revolusi industry 4.0 ini khususnya dalam proses pembelajaran berbasis elektronik dan bukan konvensional lagi. Proses pembelajaran berbasis elektronik telah di praktekan kedalam kurikulum Pendidikan keperawatan di hampir seluruh negara-negara didunia. ${ }^{1}$ Pembelajaran berbasis elektronik mampu meningkatkan fleksibilitas mahasiwa terhadap cara belajar mereka. ${ }^{1}$

Perkembangan teknologi dengan adanya sistem virtual reality sudah memainkan peran tersendiri dalam proses pembelajaran di Pendidikan keperawatan hampir seluruh dunia. Lingkungan proses belajar mengajar secara tradisional sudah statis, tidak menantang lagi, dan sering menjadi hal yang membosankan bagi para siswa di bandingkan dengan penggunaan game education yang dapat membuat sistem Pendidikan kembali bersaing lagi dalam peningkatan proses pembelajaran yang aktif. ${ }^{2}$

Penggunaan sistem pembelajaran berbasis elektronik dalam Pendidikan keperawatan mampu menciptakan pengalaman yang menarik bagi mahasiswa. Pengalaman dalam proses pembelajaran yang dimaksud adalah mahasiswa memperoleh pengetahuan baru yang terarah sesuai dengan konten pembelajaran yang diterima. $^{3}$ Salah satu bentuk pembelajaran berbasis elektronik adalah penggunaan platform game education. Dalam penggunaannya, Mahasiswa dituntuk untuk aktif dalam proses belajar, sehingga dapat mengetahui kekuatan dan kelemahan serta kemampuan mereka untuk merencanakan rencana pembelajaran kedepan. ${ }^{4}$ Penggunaan Platform game education memberikan kemudahan dalam memahami sistem pembelajaran, namun ini ditentukan oleh persepsi mahasiswa dalam kemudahan memainkan game tersebut. ${ }^{5}$

Umumnya, prestasi dan motivasi anak dapat meningkat dengan memainkan game dalam PUSLITBANG Sinergis Asa Professional, Jember computer. ${ }^{6}$ Pada orang dewasa, Pengetahuan yang diperoleh menjadi langgeng dengan memainkan video game dari pada buku teks maupun menonton televisi. Sebuah penelitian menyatakan bahwa penggunaan video dalam pembelajaran lebih baik dengan menggunakan game atau media teknologi baru lainnya menurut pengakuan $88 \%$ mahasiswa keperawatan. ${ }^{7}$ Proses pembelajaran yang menarik terjadi ketika adanya interaksi dan umpan balik dan ini dapat diperoleh melalui pembelajaran menggunakan platform game education. Oleh karena itu penulis merasa tertarik untuk melakukan studi literatur mengenai efektifitas penggunaan platform game education pada Pendidikan keperawatan.

\section{METODOLOGI}

Metode penulisan artikel ini menggunakan Literature Review yang didapat melalui pencarian elektronik dari 2 data based, yaitu: Science Direct dan Scopus,. Kriteria inklusi telaah jurnal ini adalah free fulltext, berbahasa inggris, dan terbit tahun 2013-2018. Kata kunci yang digunakan dalam pencarian adalah; Game, Education Game, Platform game education, Game Education Nursing.

Dari pencarian ditemukan 294 artikel, yang kemudian direview dengan membaca bagian judul dan abstrak hingga ditemukan 10 artikel yang relevan. Ke-10 artikel yang relevan tersebut membahas mengenai penggunaan media elektronik berupa game dalam proses pembelajaran, walaupun ke-10 artikel tersebut menggunakan teknik sampling dan desain penelitian yang berbeda satu sama lain, namun memiliki sampel tindakan dan analisis serta hasil dan kesimpulan yang sesuai dan relevan mengenai penggunaan media elektronik yakni Platform Game Education untuk dapat diterapkan dalam Pendidikan keperawatan.

\section{HASIL DAN PEMBAHASAN}

Berdasarkan 10 artikel yang dianalisis, diketahui bahwa penggunaan game education dalam Pendidikan keperawatan memiliki manfaat dalam menunjang proses pembelajaran seperti yang ditampilkan pada table 1 . 
Tabel 1

Manfaat penggunaan platform game education dalam pendidikan keperawatan

\begin{tabular}{|c|c|c|c|c|}
\hline Peneliti & Tahun & $\begin{array}{c}\text { Desain } \\
\text { Penelitian }\end{array}$ & Negara & Hasil Penelitian \\
\hline Boctor & 2013 & A Case Study & USA & $\begin{array}{l}\text { penggunaan game dalam proses } \\
\text { pembelajaran membuat metode } \\
\text { pembelajaran menjadi nyaman dan } \\
\text { sangat bermanfaat }\end{array}$ \\
\hline $\begin{array}{l}\text { Verkuyl, Atack, } \\
\text { Mastrilli, \& } \\
\text { Romaniuk }\end{array}$ & 2016 & $\begin{array}{l}\text { A Usability } \\
\text { Study }\end{array}$ & Canada & $\begin{array}{l}\text { penggunaan virtual gaming dalam } \\
\text { proses pembelajaran keperawatan } \\
\text { anak membuat para siswa merasa } \\
\text { puas }\end{array}$ \\
\hline Lin et al. & 2017 & $\begin{array}{l}\text { Literature } \\
\text { Review }\end{array}$ & Taiwan & $\begin{array}{l}\text { para siswa merasa puas dengan } \\
\text { penggunan computer game-based } \\
\text { karena pengoperasiannya yang } \\
\text { mudah dilakukan }\end{array}$ \\
\hline $\begin{array}{l}\text { Strickland \& } \\
\text { Kaylor }\end{array}$ & 2016 & A Case Study & USA & $\begin{array}{l}\text { itu penggunaan game education juga } \\
\text { mendapatkan feedback positive dari } \\
\text { para siswa dan pihak fakultas dalam } \\
\text { metode pembelajaran karena } \\
\text { lingkungan pembelajaran semua } \\
\text { difokuskan kepada para siswa }\end{array}$ \\
\hline
\end{tabular}

\begin{tabular}{|c|c|c|c|}
\hline $\begin{array}{l}\text { Verkuyl, } \\
\text { Romaniuk, Atack, } \\
\text { \& Mastrilli }\end{array}$ & 2017 & $\begin{array}{c}\text { An Experiment } \\
\text { Study }\end{array}$ & Canada \\
\hline
\end{tabular}

pengguaan virtual gaming simulation dalam Pendidikan keperawatan juga mampu membuat para siswa mengalami peningkatan self-efficacy atau keyakinan diri terhadap kemampuan yang dimiliki

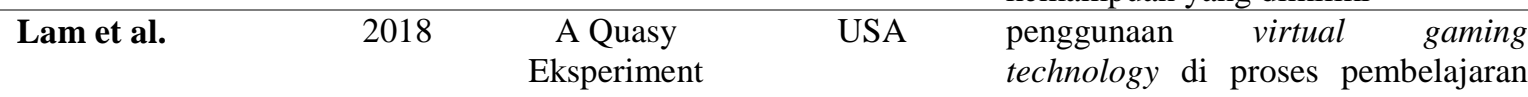
jurusan farmasi mengatakan adanya peningkatan pembelajaran dan keterlibatan para siswa apoteker di kelas, namun tidak ada perbedaan yang signifikan secara statistic terhadap komunikasi dan kerja sama tim dalam proses pembelajaran di kelas

Johnsen, Fossum, 2018 A Pilot Study
Vivekananda-
Schmidt, Fruhling,
\& Slettebø

tidak ada perbedaan yang signifikan dibandingkan dengan pembelajaran biasa yang dilakukan dikelas terkait penggunaan video-based serious game's dalam Pendidikan keperawatan, namun penggunaan didalam kursus simulasi kesehatan yang dilakukan diluar sekolah menunjukan adanya peningkatan dalam kemampuan penalaran dan pengambilan keputusan klinis oleh para peserta.

\begin{tabular}{|c|c|c|c|c|}
\hline $\begin{array}{l}\text { Verkuyl, M., } \\
\text { Hughes, M.a, Tsui, } \\
\text { J.a, Betts, L.b, St- } \\
\text { Amant, O.c, } \\
\text { Lapum }\end{array}$ & 2017 & A Focus Group & Canada & $\begin{array}{l}\text { ditemukan lima tema yakni (a) } \\
\text { pengalaman pembelajaran, (b) Proses } \\
\text { Pembelajaran, (c) personal versus } \\
\text { profesinal, (d) self-efficay, dan (e) } \\
\text { Pengetahuan. Simulasi permainan } \\
\text { virtual memberikan pengalaman } \\
\text { pembelajaran dengan melibatkan dan }\end{array}$ \\
\hline
\end{tabular}




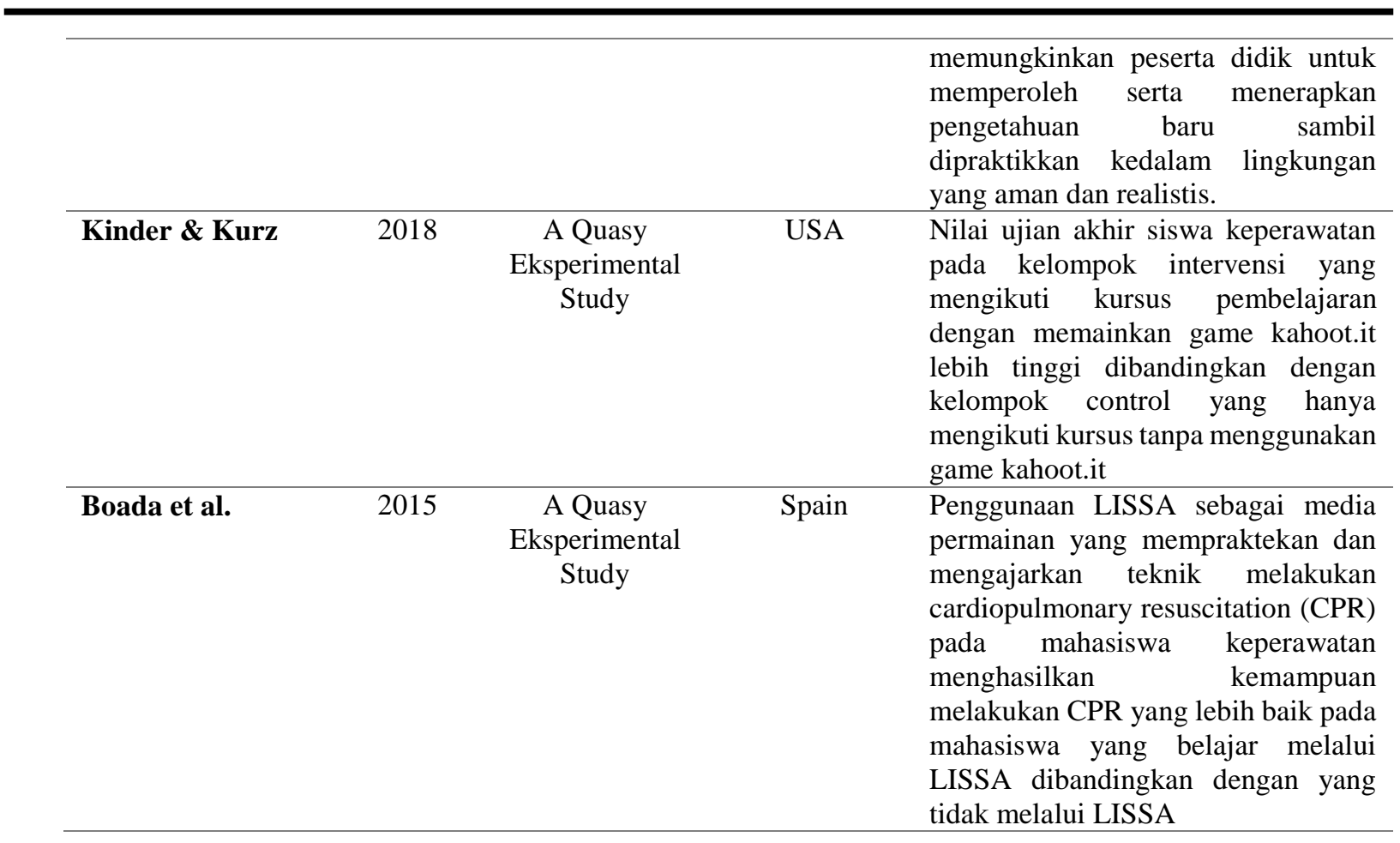

Game adalah sebuah aktifitas yang memiliki aturan bagi pemainnya yang bersaing dengan menggunakan kemampuan, pengetahuan dan keterampilan untuk mencapai tujuan yang telah ditetapkan. Dengan pengalaman yang diperoleh ketika memainkan sebuah permainan dalam proses pembelajaran, mahasiswa diharapkan mampu memahami antara materi yang ada dalam game dan praktek teori, serta keterlibatan mahasiswa menjadi meningkat dalam proses pembelajaran. ${ }^{15}$ Game memberi banyak keuntungan dalam model pembelajaran karena menggunakan stimulus audio dan visual. ${ }^{8}$ Penggunaan game dalam memperkuat Pendidikan keperawatan dapat menjadi metode pembelajaran yang menyenangkan dan bermanfaat. $^{8}$

Game education adalah game yang diakses oleh komputer yang dijadikan sebagai model pembelajaran untuk mengembangkan materi pembelajaran dan praktik klinis yang dikemas secara virtual reality, dan bukan hanya sebagai hiburan semata. ${ }^{9}$ Konten permainan yang berisi materi pembelajaran yang diarahkan seperti kegiatan praktikum dilaboratorium yang ditampilkan secara virtual reality. Pentingnya penggunaan platform game education dalam pembelajaran karena game itu sendiri sangat menarik sehingga dapat meningkatkan minat mahasiswa untuk memainkannya yang berakibat pada kegiatan pembelajaran, pemikiran dan motivasi mahasiswa dapat meningkat. Game education juga mampu membuat proses pembelajaran semakin menarik dan mampu meningkatkan kemampuan pemecahan masalah dan berfikir kritis mahasiswa. ${ }^{16}$

Salah satu jenis game education yakni Penggunaan virtual gaming simulation dengan simulasi langsung di laboratorium dapat menjadi seperangkat praktik pembelajaran terbaik dalam Pendidikan keperawatan. Virtual gaming dapat dijadikan sebagai model pembelajaran yang mampu memberikan pengalaman belajar yang berkualitas terutama dalam praktik klinik. ${ }^{10}$ Selain itu penggunaan virtual gaming reality juga memberikan peluang dalam memperoleh pengalaman pembelajaran tersendiri bagi siswa karena ilmu yang diperoleh langsung dipraktikan dalam suatu lingkungan yang aman serta realistis. ${ }^{12}$ Penggunaan virtual gaming dalam pembelajaran juga meningkatkan pengalaman pembelajaran bagi para siswa, proses pembelajaran yang dirasa menarik, sikap professional yang ditunjukan, meningkatkan kemampuan diri serta meningkatkan pengetahuan. ${ }^{12}$ Penelitian lainnya menyebutkan 
bahwa penggunaan game dalam Pendidikan dengan berbasis video dapat memberikan peningkatan dalam kemampuan penalaran dan pengambilan keputusan para siswa. ${ }^{11}$ Skenario yang diberikan dalam game education berbasis video lebih mudah dipahami terutama yang berhubungan dengan kegiatan praktik klinis. Selain itu aspek dari grafis video yang ditampilkan membuat para siswa yang memainkannya seolah merasa nyata dengan informasi dan konteks visual yang terperinci. ${ }^{11}$

Penggunaan simulasi pembelajaran dan praktik klinik terhadap sebuah kasus, memberikan pengaruh yang efektif dalam peningkatan pengetahuan para siswa serta meningkatkan keinginan mereka untuk melakukannya lebih baik lagi terutama dalam praktik klinik secara langsung. ${ }^{9}$ Hal ini akan berdampak pada capaian pembelajaran yang meningkat serta menumbuhkan minat siswa untuk belajar lebih giat lagi. Oleh karena itu perlunya dukungan dalam penggunaan game education sebagai sarana pembelajaran yang berpusat pada para siswa untuk dapat meningkatkan proses belajar, minat siswa terhadap materi yang diajarkan serta motovasi siswa untuk belajar. ${ }^{3}$

Walaupun memberi dampak positif bagi Pendidikan keperawatan, namun tak sedikit pula para siswa yang merasa kurang puas dengan penggunaan platform game education, tetapi hal ini lebih cenderung ke tampilan, bentuk permainan yang sulit untuk dipahami serta materi pembelajaran yang sulit. ${ }^{17}$ Oleh karena itu perlunya pengembangan lebih spesifik lagi terutama mengenai konten pembelajaran yang diberikan agar meningkatkan kepuasan mahasiswa dalam memainkannya.

Walaupun banyak studi yang menyajikan dampak positif yang diberikan dalam penggunaan platform game education di Pendidikan keperawatan, namun hal ini masih sangat sulit diterapkan karena membutuhkan biaya yang besar untuk pengembangan platform tersebut. Penambahan fitur-fitur dalam platform game education untuk pengembangan membutuhkan biaya yang tinggi. ${ }^{9}$ Selain itu untuk pengembangan platform game juga tidak sesederhana untuk menjadi permainan yang menyenangkan, tetapi harus terintegrasi kedalam kurikulum Pendidikan keperawatan, sehingga ketika memainkan platform game education tersebut mahasiswa diharapkan terlibat secara langsung dan aktif dalam virtual reality yang dimainkan. ${ }^{4}$

\section{SIMPULAN DAN SARAN}

Pentingnya penggunaan platform game education dalam proses pembelajaran di pendidikan keperawatan memiliki dampak positif bagi peningkatan prose belajar mahasiswa, mampu menciptakan suasana Pembelajaran yang aktif, materi pembelajaran yang disajikan dapat dipahami secara langsung melalui virtual reality serta meningkatkan kemampuan mahasiswa dalam praktik klinis. Perlu dilakukan penelitian atau kajian terkait efektifitas penggunaan platform game education dalam Pendidikan keperawatan untuk mendukung hasil kajian literature ini

Walaupun pengembangan platform game education memiliki biaya yang tidak sedikit, diharapkan institusi pendidikan mulai untuk mengembangkan platform game tersebut. Banyaknya industry game yang berkembang pesat saat ini di dunia dapat juga menjadi bahan kerja sama dengan institusi Pendidikan untuk mengembangkan jenis platform game education yang dapat digunakan dalam dunia Pendidikan, sehingga game yang yang dihasilkan tidak hanya sebagai hiburan namun memiliki dampak positif ke proses pembelajaran.

\section{UCAPAN TERIMA KASIH}

Ucapan terimakasih kepada Universitas Indonesia sebagai kampus tempat penulis menempuh Pendidikan, terimakasih kepada dosen mata kuliah Sistem Informasi Manajemen yang telah melatarbelakangi penulis melakukan studi literatur mengenai penggunaan platform game edukasi dalam sistem pembelajaran ilmu keperawatan, serta ucapan terimakasih juga ditujukan kepada teman-teman kuliah yang telah memberikan semangat dan motivasi dalam penyelesaian artikel ini 


\section{REFERENSI}

1. Button D, Harrington A, Belan I. Elearning \& information communication technology (ICT) in nursing education: A review of the literature. Nurse Educ Today. 2014;34(10):1311-23.

2. Lam JT, Gutierrez MA, Goad JA, Odessky L, Bock J. Use of virtual games for interactive learning in a pharmacy curriculum. Curr Pharm Teach Learn. 2018;(January):4-10.

3. Strickland HP, Kaylor SK. Bringing your agame: Educational gaming for student success. Nurse Educ Today. 2016;40:1013.

4. Kolb DA. Experiential learning: experience as the source of learning and development. Prentice Hall; 1984. 4-10 p.

5. Lin HC, Chiu YH, Chen YJ, Wuang YP, Chen CP, Wang CC, et al. Continued use of an interactive computer game-based visual perception learning system in children with developmental delay. Int J Med Inform. 2017;107(September 2017):76-87.

6. Papastergiou M. Digital Game-Based Learning in high school Computer Science education: Impact on educational effectiveness and student motivation. Comput Educ. 2009 Jan;52(1):1-12.

7. Lynch-Sauer J, VandenBosch TM, Kron F, Gjerde CL, Arato N, Sen A, et al. Nursing Students' Attitudes Toward Video Games and Related New Media Technologies. J Nurs Educ. 2011 Sep;50(9):513-23.

8. Boctor L. Active-learning strategies: The use of a game to reinforce learning in nursing education. A case study. Nurse Educ Pract. 2013;13(2):96-100.

9. Verkuyl M, Atack L, Mastrilli P, Romaniuk D. Virtual gaming to develop students' pediatric nursing skills: A usability test. Nurse Educ Today. 2016;46:81-5.

10. Verkuyl M, Romaniuk D, Atack L, Mastrilli P. Virtual Gaming Simulation for Nursing Education: An Experiment. Clin Simul Nurs. 2017;13(5):238-44.

11. Johnsen HM, Fossum M, VivekanandaSchmidt P, Fruhling A, Sletteb $\varnothing$ A. Nursing students' perceptions of a video-based serious game's educational value: A pilot study. Nurse Educ Today. 2018;62(December 2017):62-8.

12. Verkuyl, M., Hughes, M.a, Tsui, J.a, Betts, L.b, St-Amant, O.c, Lapum JL. Virtual gaming simulation in nursing education: A focus group study. J Nurs Educ. 2017;56(5):274-80.

13. Kinder FDA, Kurz JM. Gaming Strategies in Nursing Education. Teach Learn Nurs. 2018;13(4):212-4.

14. Boada I, Rodriguez-Benitez A, GarciaGonzalez JM, Olivet J, Carreras V, Sbert M. Using a serious game to complement CPR instruction in a nurse faculty. Comput Methods Programs Biomed. 2015;122(2):282-91.

15. Bliemel, M. \& Ali-Hassan, H. Game based experiential learning in online management information systems classes using intel's IT Manager 3. Inf Syst Educ. 2014;25(2):11724.

16. Cooper S, Cant R, Bogossian F, Kinsman L, Bucknall T, Beauchamp A, et al. Patient deterioration education: Evaluation of faceto-face simulation and e-simulation approaches. Clin Simul Nurs. 2015;11(2):97-105.

17. Gallegos C, Tesar AJ, Connor K, Martz K. Nurse Education in Practice The use of a game-based learning platform to engage nursing students : A descriptive, qualitative study. Nurse Educ Pract. 2017;27:101-6. 